\title{
The Degree of Academic Leaders' Practice of Excellence Management in Jordanian Public and Private Universities from the Faculty Members' Viewpoint
}

\author{
Rawan Kheder Yousef Abu Shaqra ${ }^{1}$ \\ ${ }^{1}$ Department of Fundamentals and Educational Management, Faculty of Educational Sciences, The Hashemite \\ University, Jordan \\ Correspondence: Dr. Rawan Kheder Yousef Abu Shaqra, Department of Fundamentals and Educational Management, \\ Faculty of Educational Sciences, The Hashemite University, P.O. Box. 330127, Zarqa 13133, Jordan.
}

Received: October 31, 2020

Accepted: November 25, 2020

Online Published: December 7, 2020

doi:10.5430/ijhe.v10n2p201

URL: https://doi.org/10.5430/ijhe.v10n2p201

\begin{abstract}
This study aimed to identify the degree of academic leaders' practice of excellence management in public and private Jordanian universities (Yarmouk University, University of Science and Technology, Al Al-Bayt University, Irbid National University, Jadara University, and Jerash University) from the faculty members' viewpoint. The descriptive survey method was adopted and to achieve the objectives of the study, a questionnaire was built to measure the degree of practicing excellence management consisting of (32) items distributed into (4) areas: leadership (10) items, policies, and strategies (5) items, human resources (5) items, and partnerships and resources (12) items. The study population consisted of all the (2077) faculty members in the Jordanian public and private universities in the first semester of the academic year 2020/2021. Where the study sample consisted of (405) academics who constitute (19\%) of the study population. and were selected by a random stratified method. The results showed that the overall degree of academic leaders' practicing of excellence management in the public and private Jordanian universities was moderate, and the order of the areas on the scale was respectively as follows; Partnerships and Resources, leadership, Policies and strategies, and human resources, and that all of these areas came at a moderate degree. The results also showed that there were statistically significant differences at the level of statistical significance $(\alpha=0.05)$ between the estimates of respondents in all areas (leadership, policies and strategies, human resources, partnerships, and resources) attributable to the difference in; the gender variable in favor of males, academic rank in favor of the professor, and the type of university in favor of public universities. Regarding these results, the researcher recommends giving more attention to the Department of Excellence, especially in the field of leadership, as well as the inclusion of Excellence Management as a basic criterion of performance quality standards in Jordanian public and private universities.
\end{abstract}

Keywords: excellence management, academic leaders

\section{Introduction}

Information and knowledge revolution have brought out global challenges that necessitated a dramatic shift in all areas, especially in higher education institutions. As a result of the rapid transformations, it was necessary to bring about a change in the administrative methods of universities. Therefore, several public universities recognized the necessity to develop future perceptions of their management based on excellence, creativity, and orientalism of the future, and to reconsider their philosophy, vision, university mission, and all educational plans and programs. In addition to developing the skills of educational staff and academic leaders, educational structures, goals that they seek to achieve. And to reconsider their interaction with the local community and the need to strengthen the ties between them and to flexibly contribute to community development (Brrazi, 2015). Shawqy (2010) believes that the survival of institutions and their adaptation to these situations are accomplished by providing good leadership capable of finding and investing opportunities, mitigating risks, acting skillfully, and planning effective strategies.

In 2012, the European Foundation for Quality Management (ENQA) launched five working groups to respond to the needs to develop ideas, share knowledge, and experience among the participants. ENQA working group on excellence agreed on a work program involving a mapping exercise to identify existing literature on excellence and to assess current practice. The group also agreed to draft an analytical paper to consider various approaches to the recognition of excellence in higher education and to include recommendations on how the concept could be applied in the context 
of the work of quality agencies. In the initial phase of the work of the group, there was an informed and productive discussion about the concept of excellence and how it was applied in the context of different higher education sectors. The group also looked at how the concept was understood concerning the work of quality assurance (QA) agencies and the relevance of excellence as an expectation for QA. The group also identified the difference between excellence in the management of higher education and excellence in teaching and research. It was recognized that there may be more than one way in which agencies could develop excellence in higher education. The EFQM Excellence Model establishes broad criteria, which any organization can use to assess the progress towards excellence. These nine criteria are divided between enablers and results including four main areas that are policy and strategies, people management, Partnerships and resources, and Process management (Brusoni, et al (2014). In Jordan, higher education was keen to achieve excellence in universities by preparing 8 quality standards for universities, which included several areas: strategic planning, governance, academic programs, scientific research, human, financial, and student resources, community service, and quality assurance. Universities were also keen to prepare their visions and goals based on these criteria.

\subsection{The Concept and Origin of Excellence Management}

The term Excellence Management in the Arabic language is derived from the stem verb "mayaz" and it is said that the people are "Tamayz" means being distinguished, that is, they are pioneers and distinctive (Arabic Language Academy, 1985,929). Where in English it means "Excellence". The Greeks used it with the concept of "Mightter, Best," in the sense of "Mightter, Best" (Annios, 2007), and in the dictionary "macmillan" it is defined as quality for the individual and excellence, meaning very high quality. Excellence is a mark of distinction, describing something exceptional, meritocratic, outstanding, and exceeding normal expectations. It is a form of commendation commonly linked to the reputation of institutions and to the achievements of students (Brusoni et al, 2014) and a part of a process of which competence is the starting point (Kömürcügil, 2014) that is linked to the quality and it identifies a range of different characteristics (Malmedy, 2014) including a high level of perfection that a person or a thing has in its kind and the quality of being outstanding or extremely good. Mubarak (2013) considered it as a philosophy in management based on the principle of optimal utilization of the resources available to the institution in the best possible methods to maximize their utilization to the maximum possible degree, which supports the organization to become one of the best organizations in its field and in a way that leads to adding positive sources for all owners interest, shareholders, internal and external customers, employees and society.

Excellence management can be considered the ability to achieve coherence and consistency between all the elements of the institution to reach the highest levels of efficiency through the following four elements: a) Management: where it carries out leadership processes and determines the appropriate strategy for the organization and all levels of performance; b) Individuals: it is how to manage and direct the organizational behavior to achieve the satisfaction of working individuals; c) Systems: They are the systems related to the resources and operational processes to perform the tasks of the organization; d) Results: which focus on achieving customer satisfaction and achieving the targeted material benefits).

From the foregoing, the researcher assumes that Excellence Management is all the activities and practices that work to achieve the benefit and competitiveness of its success through the optimum expenditure of all skills, the financial and material resources available in a distinctive manner, making it distinctive and competitive at all levels both individuals and trends in the local community, how to prepare strategies and general policies for education. Some researchers believed that the characteristics of Excellence Managing were varied and distinct, Sreenivas (2014) summarized these characteristics as follows:

- Creativity: The thing that separates distinction from mastery. It is considered the catalytic that pushes forward and draws people's attention.

- The structure is the structure that contains the standards, limits, and outlines, and the academic leaders are the ones who know how to work within the framework of this structure without having any effect on the progress of the educational process so that they can effectively lead his team in light and within the existing standards.

- Self-assessment, whereby the university carries out a permanent and periodic self-review of all of its conditions for an internal evaluation and identifies weaknesses and their impact on the results achieved and the extent of their use in developing the performance of the educational institution and achieving a competitive advantage. And permanent and continuous improvement and development.

- Building relationships: that are intended to form relationships with all parties to whom the educational institution is linked, and to employ them in enhancing the institution's opportunities to achieve its goals. 
Nassif (2010) also indicated that excellence leads to the quality of work, which makes the individual enjoy the work he performs and thus achieve job satisfaction due to the few errors that may occur. Excellence, in general, seeks to achieve the efficiency of the way a person operates and since it relies on the values and philosophy of overall quality, therefore, the achievement of excellence is directly and strongly related to overall quality, provided that comprehensive quality is one of the most critical conditions for achieving excellence through a direct commitment to overall quality.

Excellence management in universities is considered one of the most important elements of the quality of university performance and given that the academic leader implements it through a set of educational policies, programs, and all appropriate processes. Therefore, the management of excellence and the quality of performance is directly related to the content of the academic activity, provided it is characterized by transparency and clarity when formulating strategies for excellence and excellence to ensure the quality of performance in the institutions of high education (Dhala'in, 2018). It can achieve many privileges and success to the university overall its competitors in higher education institutions, as it is considered one of the most important necessities for all institutions.

\subsection{Study Terms and Operational Definitions}

Practicing: The actual use of standards of excellence management by academic leaders, which include (leadership, policies and strategies, and management practices) (Al-Saud.2009). Operationally: it is the score that the respondent gives in the Management of Excellence Scale on the questionnaire prepared for this purpose.

Academic leaders: as defined by Tanash (2020), they are university presidents and their deputies, deans of colleges, and heads of departments in universities. Operationally, they are those responsible for higher administrative work in universities, including professors, faculty members, deans of colleges and heads of departments, and those who make the greatest effort to improve the academy on a continuous and permanent basis, to make the university one of the competing universities and to be able to fulfill its function effectively. And in this study, they are deans of colleges and heads of departments.

Excellence management: the ability to provide and organize the elements of the organization and to operate them in integration and interdependence to achieve the highest rates of productivity in administrative performance, and thus to achieve the level of production that meets the needs, benefits, and aspirations of the owners of the company associated with it (Suhaimi, 2016). Operationally, they are the pre-planned organizational efforts that follow at the university with a view to continuous improvement following the criteria of excellence management set out in the questionnaire, which are measured by the degree provided by the respondent in the measure of excellence management prepared for this purpose and presented in the report.

\subsection{Study Problem}

Public and private universities in Jordan eager to implement their vision and mission that focus on achieving leadership in education, learning, and community service, and their mission that confirm their role in providing education and learning for all members of the local community in line with the requirements of the local community. They also keen to strengthen the partnership Societal, which coincides with the goals of Jordanian universities and the management of excellence in their constant pursuit of achieving sustainable development, knowledge management, and building a knowledge society through providing Excellence Management. Therefore, questions were raised about the degree of academic leaders 'practice of excellence management standards and the extent of their application to these standards according to the vision and mission of the university. Hence, the study seeks to identify the degree of academic leaders' practice of excellence management in public and private Jordanian universities, and the problem of the study is evident by answering the following questions:

1) What is the degree of academic leaders' practice of excellence management in Jordanian public and private universities from the faculty members' viewpoint?

2) Are there statistically significant differences at the level of significance $(\alpha=0.05)$ between the mean for excellence management in public and private Jordanian universities among the faculty members and from their viewpoint attributable to demographic variables (gender, academic rank, and university type and college)?

\subsection{Study Objectives}

This study aimed to identify the degree of academic leaders' practice excellence management in public and private Jordanian universities from the faculty members' viewpoint. according to variables (academic rank, gender, university type), and that to benefit from the results in developing the university inputs and outputs. 


\subsection{The Importance of the Study}

The study derives its significance from the significance of Jordanian universities, both public and private, and their role in achieving comprehensive growth, the importance of faculty members and their role in achieving the objectives of the university, and the importance of high levels of excellent management practice, which affects their performance and allows them to ensure continuity and leadership. The expected importance is represented in:

1) What the results of this study may add to scientific knowledge.

2) The results of this study may contribute to presenting suggestions for applying Excellence Management in the Jordanian public and private universities to improve their performance and achieving the advancement of educational outputs and the institution's goals and objectives.

3) It is hoped that this study will benefit the Ministry of Higher Education in developing new strategies that enhance the level of Excellence Management.

4) This study provides descriptive and realistic results of the actual status of Excellence Management in Jordanian public and private universities, which may help academic and administrative leaders and policymakers in making the appropriate administrative decision to enhance these concepts among faculty members through the feedback provided by this study.

5) This study hopes to bridge the gap in scientific research in this field,

\subsection{Study Limits}

- Time limits: The study was conducted during the second semester of the 2020/2021 academic year.

- Spatial boundaries: public and private universities, which are: Yarmouk University, University of Science and Technology, Al Al-Bayt University, Irbid National University, Jadara University, and Jerash University.

- Objective limits: This study and its results are determined by data collection tools, and the nature of society, and the sample of faculty members.

\section{Previous Studies}

Enezi (2019) conducted a study aimed at identifying the degree of the practice of secondary school principals in the State of Kuwait to manage excellence in the light of the European model of excellence from the teachers' point of view. The study population consisted of (1782) all high-school teachers in Al-Jahraa Governorate in the State of Kuwait. The randomly selected sample consisted of (345) teachers. The descriptive survey approach and the researcher developed a questionnaire consisting of (31) items, divided into five areas (leadership, policies, human resources, relations with the local community, and community service). The results showed that: a) There were no statistically significant differences in the responses of the study sample attributed to gender variable in all areas except for the area of community service, and the differences were in favor of females; b) There were no statistically significant differences in the responses attributable to the different categories of academic qualification in all fields and the overall tool; c) There were no statistically significant differences due to the different categories of experience, except for the field of leadership and the overall tool; d) There were statistically significant differences between those with experience less than 5 years and 5-10 years on the one hand and 10 years or more and the differences came in favor of respondents with experience 10 years and above. The study recommended training school principals on the concepts of managing excellence through holding seminars, workshops, and directive leaflets to raise awareness of the importance and benefits of applying the elements of excellence management considering the European model.

Sahamuod (2013) conducted a study aimed at revealing the reality of excellence management at Al-Aqsa University and its methods of development according to the European Foundation for Quality and Management EFQM. To achieve the objectives of the study, the study used the descriptive and analytical method by applying a questionnaire that included European standards of excellence on a sample of (116) participants. The findings showed that the degree of Excellence in Management at Al-Aqsa University according to the standards of excellence was moderate in the fields of administrative operations, policies, and strategies, and high in the field of leadership. The results also showed that there were statistically significant differences attributed to scientific qualification in favor of graduate studies, while there were no statistically significant differences due to the variable of years of experience and gender. And there were differences in favor of scientific colleges with the rank of professor, and there were differences in the responses of the study sample attributable to public universities.

In 2016, a study was conducted to identify the extent to which the leadership standard is applied in Palestinian higher education institutions under the European model of excellence by Saada. To achieve the objectives of the study, the 
researcher adopted a descriptive approach by using a questionnaire consisting of (30) items. The study sample comprised (45) academic administrators including the deans and heads of departments in Palestinian universities. The results of the study showed that the degree of leadership practice came at a moderate degree on all dimensions of the leadership criterion, and there were no statistically significant differences in the degree of practice attributable to gender and job position variables. Also, it indicated that there were differences attributable to variable experience and in favor of group (5 years and above), there were differences in favor of the academic rank and favor of professor.

Maher (2020) conducted a study aimed at identifying the availability of requirements for the application of EFQM standards at the University of Najran considering some international experiences from the viewpoint of university leaders and faculty members. The researcher used the descriptive approach to achieve the goals of the study and built a questionnaire to measure the extent to which the requirements are met. The questionnaire consisted of (61) items distributed on (9) areas. The findings showed that leaders and faculty members at Najran University have all the requirements of excellence management standards and there were no statistically significant differences in the responses of faculty members between the respondents attributed to the variables; gender, position, nationality, specialization, and occupation. The results also showed that there were significant differences attributable to the leadership variable in the areas (human resources in favor of non-leadership), there were differences due to the variable of experience in the area (policies and strategies, Human resources and employee satisfaction), and there were differences in favor of humanitarian colleges.

Mahalaqi (2018) conducted a study aimed at identifying the degree of application of the King Khalid University leadership to the standards of Excellence in Management in light of the European Model (EFQM) from the viewpoint of the faculty members, and to achieve the research objectives, the researcher used the descriptive approach, and a questionnaire was constructed consisting of 350 items, The results of the study concluded that the application of the standards was of a moderate degree, and the results also found that there are statistically significant differences due to the variable of specialization between the required specializations and in favor of the human specialties, and the presence of statistically significant differences attributed to the variable of the academic degree and in favor of the degree of an assistant professor, and the absence of relevant differences Statistical significance attributed to the variable of the number of years of university service.

Zoubi (2019) conducted a study aimed to identify the degree of high school principals' practice of the standards of excellence management according to the EFQM model of administrative excellence in Beni Kenana District. To achieve the objectives of the study, the researcher used a descriptive approach to collect data and information. The study sample consisting of 15 principals and principals. The study showed that the degree of principals' practice of performance standards was beneficial, and it also showed that there were no statistical differences in the degree of the principals' practice of the standards of excellence for the policy variables attributed to (gender, administrative experience and academic qualification)

In 2015, Perrini addressed the concept of the EFQM Excellence Model and the most important benefits that the institution will achieve from an administrative point of view. It also described the basics provided by the model. The Excellence Management Model was divided into two basic parts, the first consisting of five basic elements that are considered introductory, and the second consists of four results. It also set an insightful way on how to apply excellence. In addition to a detailed explanation, the study concluded that the most important feature of the EFQM Excellence Model is the ability to help managers obtain a complete view of the organization, and an opportunity to compare competitors in departments. Where Ahmed (2015) sought to identify the reality and obstacles to institutional performance at the South valley University considering European standards of excellence. The results of the study indicated the availability of all standards of the European Excellence in Management with a moderate degree and the lack of funding and the absence of modern systems for evaluating the performance of employees. The results also indicated that the heavy academic and administrative burdens are the main obstacles facing the application of the model at the South Valley University, and there were no differences in the study sample responses due to the gender variable.

Moeini (2015) aimed to scrutinize the performance of the Joghatay educational system based on the EFQM organizational model. Five dimensions of the model including Leadership, Policy and Strategy, People, Partnerships and Resources, and Processes of the Joghatay Office of Education. To achieve the objectives of the study, the researcher used the descriptive approach and a questionnaire that was distributed to a randomly selected sample of (104) participants. The overall findings of the study indicated that there was a significant relationship between the EFQM organizational excellence model and the performance of the educational system of Joghatay where $47 \%$ of the performance changes were influenced by the EFQM model criteria. It also showed that there were differences in the responses of the participants attributed to the gender variable in favor of females, and there were no differences in the 
responses due to the college variable. After reviewing the previous studies we conclude that some studies focused on the reality of applying the criteria for excellence management, such as the study of Suaada (2016), Enezi (2019), AlSahamud (2013), Maher (2020), Ahmed (2016), Moeini (2015) and Perrini (2015), while the current study is unique and distinguished in its goal, which is to reveal the degree of academic leaders' practice of excellence management in public and private Jordanian universities from the faculty member viewpoint within the limits of the researcher's knowledge as this study is distinguished in her environment, as no such study has been conducted.

\section{Methods and Procedures}

This chapter presents the methodology used in the study, it describes the study population, sample, tools, and methods used to check the validity and reliability of these tools. It also includes the study variables; the statistical treatment used to analyze the data and interpret the findings.

\subsection{Study Approach}

The descriptive survey method was adopted because it is appropriate for the nature of this study and its objectives.

\subsection{Study Population and Sample}

The study population consisted of all the (2077) faculty members in public and private universities in the North Region in Jordan during the first semester of the academic year 2020/2021. The researcher selected a random sample consisting of (405) faculty members in public and private universities in the North Region, where the questionnaires were distributed electronically to all the participants. All the questionnaires were retrieved, and they were all subject to analysis and coding, they represent (19.4\%) of the study population as shown in Table 1.

Table 1. Distribution of the study sample

\begin{tabular}{llll}
\hline Variables & Categories & Frequency & Percent \\
\hline Gender & Male & 212 & $52.3 \%$ \\
& female & 193 & $47.7 \%$ \\
Academic rank & Total & 405 & $100.0 \%$ \\
& professor & 110 & $27.2 \%$ \\
& Co-professor & 122 & $30.1 \%$ \\
University type & Assistant Professor & 173 & $42.7 \%$ \\
& Total & 405 & $100.0 \%$ \\
& Own & 239 & $59.0 \%$ \\
College & Government & 166 & $41.0 \%$ \\
& Total & 405 & $100.0 \%$ \\
& Humanity & 210 & $51.9 \%$ \\
& Scientific & 195 & $48.1 \%$ \\
& Total & 405 & $100.0 \%$ \\
\hline
\end{tabular}

\subsection{Study Tool}

The researcher developed the study tool by referring to the relevant theoretical literature, and the previous studies related to this subject such as (Al-Ghuwairi, 2018). The questionnaire consisted of (32) items distributed into (4) areas which are: Leadership (10) items, Policies, and strategies (5) items, Human resources (5) items, and Partnerships and Resources (12) items.

\subsubsection{Study Validate}

a. Content validity: To check the content validity, it was presented in its initial form to (10) experienced arbitrators from Education College in the Jordanian universities to check the items' relevance to the scale and its soundness. All the arbitrators' suggestions were considered. And the recommended modification that they agreed on with a percent of $(80 \%)$ was achieved.

b. Construct validity: To verify the construct validity, the study tool was applied to an exploratory sample consisting of (30) faculty members from Jordanian universities, from outside the study sample. To identify the validity of the 
internal consistency of the tool the Pearson correlation coefficient was calculated for the items of the study tool with the overall degree of its field as shown in Table 2.

Table 2. Pearson correlation coefficient for the items of the tool with the overall degree of its field

\begin{tabular}{lllllllll}
\hline \multicolumn{1}{c}{ Leadership areas } & \multicolumn{1}{c}{ Policies \& strategies } & Human resources & Partnership\& resources \\
\hline \multicolumn{1}{c}{$\begin{array}{l}\text { correlation } \\
\text { coefficient }\end{array}$} & Sig & $\begin{array}{l}\text { correlation } \\
\text { coefficient }\end{array}$ & Sig & $\begin{array}{l}\text { correlation } \\
\text { coefficient }\end{array}$ & Sig & $\begin{array}{l}\text { correlation } \\
\text { coefficient }\end{array}$ & Sig \\
1 & $0.800^{* *}$ & 0.000 & $0.809^{* *}$ & 0.000 & $0.750^{* *}$ & 0.000 & $0.802^{* *}$ & 0.000 \\
2 & $0.839^{* *}$ & 0.000 & $0.805^{* *}$ & 0.000 & $0.640^{* *}$ & 0.000 & $0.853^{* *}$ & 0.000 \\
3 & $0.781^{* *}$ & 0.000 & $0.828^{* *}$ & 0.000 & $0.700^{* *}$ & 0.000 & $0.631^{* *}$ & 0.000 \\
4 & $0.798^{* *}$ & 0.000 & $0.812^{* *}$ & 0.000 & $0.597^{* *}$ & 0.000 & $0.812^{* *}$ & 0.000 \\
5 & $0.763^{* *}$ & 0.000 & $0.881^{* *}$ & 0.000 & $0.749^{* *}$ & 0.000 & $0.831^{* *}$ & 0.000 \\
6 & $0.823^{* *}$ & 0.000 & & & & & $0.772^{* *}$ & 0.000 \\
7 & $0.809^{* *}$ & 0.000 & & & & & $0.696^{* *}$ & 0.000 \\
8 & $0.825^{* *}$ & 0.000 & & & & & $0.817^{* *}$ & 0.000 \\
9 & $0.775^{* *}$ & 0.000 & & & & & $0.724^{* *}$ & 0.000 \\
10 & $0.750^{* *}$ & 0.000 & & & & & $0.839^{* *}$ & 0.000 \\
11 & & & & & & & $0.555^{* *}$ & 0.000 \\
\hline
\end{tabular}

** Statistically significant at $(0.01=\alpha)$ level.

* Statistically significant at $(0.05=\alpha)$ level.

Table 3 shows that the values of the items correlation coefficients were as follows; Leadership ranged between $(0.750$ - 0.839) with the field, Policies and strategies ranged between $(0.805-0.881)$ with the field, Human resources ranged between $(0.597-0.750)$ with the field, and Partnerships and resources ranged between $(0.555-0.853)$ with the field, which means that all these values were statistically significant and accordingly the internal consistency in the items on the scale were valid. Table 3 shows the values of the Pearson correlation coefficients between the fields of the tool and its overall score.

Table 3. The Pearson correlation coefficients between the fields of the tool and the too overall score.

\begin{tabular}{|c|c|c|c|c|c|}
\hline Fields & Leadership & Policies strategies & $\begin{array}{l}\text { Human } \\
\text { resources }\end{array}$ & $\begin{array}{l}\text { Partnership \& } \\
\text { resources }\end{array}$ & $\begin{array}{l}\text { Overall } \\
\text { Scales }\end{array}$ \\
\hline Leadership & 1 & $0.762 * *$ & $0.669^{* *}$ & $0.532 * *$ & $0.824 * *$ \\
\hline Policies \& strategies & & 1 & $0.874 * *$ & $0.620 * *$ & $0.860 * *$ \\
\hline Human resources & & & 1 & & $0.880 * *$ \\
\hline $\begin{array}{l}\text { Partnership } \\
\text { resources }\end{array}$ & & & & 1 & $0.786^{* *}$ \\
\hline Overall Scales & & & & & 1 \\
\hline
\end{tabular}

** Statistically significant at $(0.01=\alpha)$ level.

* Statistically significant at $(0.05=\alpha)$ level.

Table 3 illustrates that there are high correlation coefficients that are statistically significant at $(0.05=\alpha)$ between the fields with the overall score of the scale, which ranged between $(0.786-0.880)$, which means that the internal consistency between the fields and the overall score on the scale is valid.

\subsubsection{Study Reliability}

To verify the reliability of the study tool, Cronbach`s Alpha internal consistency method was applied. The tool was applied to a sample consisting of (30) faculty members in Jordanian universities, from outside the target study sample as shown in Table 4. 
Table 4. Cronbach Alpha for internal consistency

\begin{tabular}{llll}
\hline NO. & Field & Cronbach Alpha & Items \\
\hline 1 & leadership & 0.909 & 10 \\
2 & Policies \& strategies & 0.868 & 5 \\
3 & Human resources & 0.870 & 5 \\
4 & Partnership \& resources & 0.899 & 12 \\
Total & & 0.921 & 32 \\
\hline
\end{tabular}

Table 4 shows that the values of the Cronbach's Alpha reliability Coefficients for the academic leaders' degree of practice Excellence management in Jordanian public and private universities ranged between (0.870-0.909) for the fields and the value of the Cronbach Alpha reliability for the overall tool reached $(0.921)$. These values are considered appropriate for the current study.

3.3.3 Study variables

A. the independent variables:

1) Gender variable: It has two levels (male, female).

2) Academic rank variable: It has three levels (professor, associate professor, assistant professor).

3) University type variable: It has two levels (private and governmental).

4) College variable: It has two levels (humanitarian and scientific).

B. Dependent Variables:

- The degree of academic leaders' practice excellence management in Jordanian public and private universities from the faculty members' viewpoint.

\subsection{Statistical Treatment}

The statistical treatments of the study data were carried out using the Statistical Package for Social Sciences (SPSS).

- To answer the first question, means, standard deviations, and ranks of the tool were extracted.

- To answer the second question, (MANOVA) analysis was used on the excellence management in public and private Jordanian universities among academic leaders attributable to demographic variables (gender, academic rank, type of university, and college). And the Post Hoc Comparisons (Scheffe) was used.

- Frequencies and percentages were gauged to determine the distribution of the study sample according to the variables.

- The Cronbach-Alpha was used to find the internal consistency coefficient, to check the reliability of the study tool.

- Pearson correlation coefficient was used to find the internal consistency validity coefficient for the study tool items.

- The degree of academic leaders' practice of excellence management in Jordanian universities was identified in three levels. Through the following equation:

Class Length $=($ Highest Alternative Value - Minimum Alternative Value $) /$ Number of Scores

$$
=(5-1) / 3=1.33 \text { class length for an item }
$$

Accordingly, the scores became (1-2.33) low, (2.34-3.67) moderate, (3.68-5.00) high

\section{Results and Discussion}

The study aimed to identify the degree of academic leaders' practice of excellence management in Jordanian public and private universities from the faculty members' viewpoint, and to achieve these objectives, the study sought to answer the following questions:

\subsection{Results of the First Question}

"What is the degree of academic leaders' practice of excellence management in Jordanian public and private universities from the faculty members' viewpoint?" To answer the first question, means and standard deviations were gauged for the degree of academic leaders' practice excellence management in Jordanian public and private universities 
in general and each field as indicated in Table 5.

Table 5. Mean and standard deviations of the degree to which academic leaders in public and private Jordanian universities practice excellence management from the viewpoint of faculty members, arranged in descending order

\begin{tabular}{llllll}
\hline $\mathbf{N}$ & Field & Mean & SD & Rank & Degree \\
\hline $\mathbf{1}$ & Leadership & 3.12 & 1.17 & 2 & Moderate \\
$\mathbf{2}$ & Policies and strategies & 3.02 & 1.18 & 3 & Moderate \\
$\mathbf{3}$ & Human resources & 2.98 & 1.16 & 4 & Moderate \\
$\mathbf{4}$ & Partnerships and resources & 3.17 & 1.10 & 1 & Moderate \\
Overall degree & 3.10 & 1.12 & &
\end{tabular}

Moderate

Table 5 indicates that the mean of the degree of academic leaders' practice excellence management in the Jordanian public and private universities from the faculty member point of view came at a moderate degree $=3.10$ with a standard deviation $=1.12$. The field "Partnerships and Resources." ranks first with a mean $=3.17$, a standard deviation $=1.10$, and a moderate degree. The second field is "leadership" with mean $=3.12$, a standard deviation $=1.17$, and a moderate degree too. It was followed by the "policies and strategies" with a mean $=3.02$, a standard deviation $=1.18$, and a moderate degree. The field which ranked last with a mean $=2.98$ and a standard deviation $=1.16$ is "human resources" and it came at a moderate level.

Here a brief presentation of mean and standard deviations for each of the items on the fields of the degree to which academic leaders in public and private Jordanian universities practice the excellence management from the faculty members' viewpoint arranged in descending order on the field as illustrated in Table 6.

Table 6. Means and standard deviations of the items of tool arranged in descending order

\begin{tabular}{|c|c|c|c|c|c|}
\hline & ITEM & MEAN & SD & RANK & DEGREE \\
\hline 8 & $\begin{array}{l}\text { The university administration participates in implementing and } \\
\text { developing the work system and ensuring continuous improvement }\end{array}$ & 3.33 & 1.29 & 1 & MODERATE \\
\hline 10 & $\begin{array}{l}\text { The university administration provides clear and specific criteria based } \\
\text { on competence, seniority, and experience for selecting leaders }\end{array}$ & 3.30 & 1.34 & 2 & MODERATE \\
\hline 3 & $\begin{array}{l}\text { The university is interested in working on developing its strategies and } \\
\text { future }\end{array}$ & 3.27 & 1.26 & 3 & MODERATE \\
\hline 4 & $\begin{array}{l}\text { The university strives to constantly and continuously motivate academic } \\
\text { leaders }\end{array}$ & 3.17 & 1.27 & 4 & MODERATE \\
\hline 2 & The university promotes excellence management values & 3.11 & 1.27 & 5 & MODERATE \\
\hline 7 & $\begin{array}{l}\text { The university interacts with the local community to market for quality } \\
\text { and excellence outside the university }\end{array}$ & 3.08 & 1.27 & 6 & MODERATE \\
\hline 6 & $\begin{array}{l}\text { The university sets the priorities for university work, administratively } \\
\text { and academically }\end{array}$ & 3.06 & 1.27 & 7 & MODERATE \\
\hline 9 & $\begin{array}{l}\text { The university supports university work policies and team spirit within } \\
\text { the university }\end{array}$ & 2.99 & 1.25 & 8 & MODERATE \\
\hline 5 & $\begin{array}{l}\text { Allowing the continuous development and upgrading of teaching } \\
\text { methods by providing all available material resources. }\end{array}$ & 2.96 & 1.29 & 9 & MODERATE \\
\hline 1 & $\begin{array}{l}\text { The university leadership aims to develop integrated plans and policies } \\
\text { that express its future vision. }\end{array}$ & 2.95 & 1.29 & 10 & MODERATE \\
\hline \multicolumn{2}{|c|}{ LEADERSHIP TOTAL DEGREE } & 3.12 & 1.17 & \multicolumn{2}{|c|}{ MODERATE } \\
\hline 5 & $\begin{array}{l}\text { Effective performance indicators are set to objectively identify the extent } \\
\text { to which policies and strategies are being implemented }\end{array}$ & 3.24 & 1.28 & 1 & MODERATE \\
\hline 4 & $\begin{array}{l}\text { University policies and strategies are subject to permanent and } \\
\text { continuous evaluation and development }\end{array}$ & 3.04 & 1.29 & 2 & MODERATE \\
\hline
\end{tabular}



University policies and strategies are based on the current and future needs and expectations of the individuals working in it

\section{POLICIES AND STRATEGIES TOTAL DEGREE}

$\mid$ The human resources system includes the mechanisms for identifying the jobs and jobs required to implement the operations and foundations of management planning and to determine their rates and levels

The university provides effective communication channels for communication between employees and their superiors

The university works to develop human resource skills and support their knowledge by undergoing continuous and periodic training

The university's human resource management system is an advanced system that shows the rules and mechanisms for planning, attracting, training, and evaluating institutional performance and the principles of compensation for employees according to performance results.

Human resources participate in the university in developing plans and strategies

\section{HUMAN RESOURCE TOTAL DEGREE}

12 The university has a system for managing buildings and various assets

3.98

1 The university has modern means of communication

The university seeks to achieve a balance between the internal, current, and future needs of the university and the local community

1.25

1.18

MODERATE

Mechanisms are available to take advantage of university information and knowledge

The university strives to foster friendly relations between working individuals

The university establishes a clear and specific mechanism for managing human resources, property, and technical facilities

The available financial resources are sufficient to cover all its expenses The university is interested in integrating technology into the educational process

The possibility of using the website to provide services to the beneficiaries

The university plans to establish internal and external partnerships to implement the university's policies and strategies

Table 6 shows that the mean of the leadership field $=3.12$ with a standard deviation $=1.17$ and a moderate degree. Item (8) stating "The university administration participates in implementing and developing the work system and ensuring continuous improvement," ranked first in this field with a mean $=3.33$, standard deviation $=1.29$, and with a moderate level. This may attribute to the eagerness of university leaders to apply the thought and philosophy of quality in all its processes, including inputs, outputs, and processes, and to emphasize permanent reform and continuous development. 
On the other hand, university leaders are following a mechanism of continuous development and awareness for the good and are implementing and disseminating policies of excellence in institutional efficiency. This result is consistent with the results of the study of Ibrahim (2020) and Zoubi (2019). In the last rank came Item (1), which stipulated "The university leadership aims to develop integrated plans and policies that express its future vision." with a mean=2.95, a standard deviation $=1.29$, and a moderate degree.

Table 6 also shows that the mean of the field policies and strategies $=3.02$ with a standard deviation $=1.18$ and a moderate degree. Item (5) which stipulated "Effective performance indicators are set to objectively identify the extent to which policies and strategies are being implemented," came in the first place and get a mean= 3.24, standard deviation $=1.28$, and with a moderate degree. The result may be due to implementing the university's vision and mission in real and effective ways and the clear specific plans and strategies. This result is consistent with the results of Moeini (2015). Item (1) states that "University policies and strategies are based on the current and future needs and expectations of the individuals working in it ", ranked last with a mean $=2.90$, a standard deviation $=1.32$, and came at a moderate level. Where the human resources field records a mean $=2.98$, a standard deviation $=1.16$, and a moderate degree. In the first rank came Item (5) which states "The human resources system includes the mechanisms for identifying the jobs and jobs required to implement the operations and foundations of management planning and to determine their rates and levels," with a mean $=3.09$, a standard deviation $=1.25$, and a moderate level. In the last rank came item (1) which states "Human resources participate in the university in developing plans and strategies," with a mean $=2.81$, a standard deviation $=1.24$, and a moderate degree.

Table 6 also shows that the partnerships and resources reached a mean $=3.17$ with a standard deviation $=1.10$ and a high degree. Item (12) which stating, "The university has a system for managing buildings and various assets," came first with a mean $=3.93$, a deviation Standard $=1.18$, and at a high level. The researcher attributes this to the eagerness of university departments and academic leaders to employ all university facilities, make the best use of them, and provide all the necessary technological tools and integrate them into the university educational process in all its aspects to achieve sustainable excellence. This study differs from the study of Sahamoud (2013). Item (1) which stated that " The university plans to establish internal and external partnerships to implement the university's policies and strategies ", ranked last with a mean $=2.70$, a standard deviation $=1.27$, and a moderate level.

\subsection{The Results of the Second Question}

"Are there statistically significant differences at the level of significance $(\alpha=0.05)$ between the mean for excellence management in public and private Jordanian universities among the faculty members and from their viewpoint attributable to demographic variables (gender, academic rank, and university type and college)? To answer the second question, means and standard deviations were gauged for the responses of participants according to the variables, academic rank, type of university, and college, as shown in Table 7.

Table 7. Means and Standard deviations for the responses according to study variables

\begin{tabular}{|c|c|c|c|c|c|}
\hline Variables & Fields & Categories & No & Mean & SD \\
\hline \multirow[t]{14}{*}{ Gender } & \multirow[t]{3}{*}{ leadership } & Male & 212 & 3.79 & 0.92 \\
\hline & & female & 193 & 2.39 & 0.94 \\
\hline & & Total & 405 & 3.12 & 1.17 \\
\hline & \multirow[t]{3}{*}{ Policy \&strategies } & Male & 212 & 3.69 & 0.99 \\
\hline & & female & 193 & 2.29 & 0.92 \\
\hline & & Total & 405 & 3.02 & 1.18 \\
\hline & \multirow[t]{3}{*}{$\mathrm{HR}$} & Male & 212 & 3.65 & 0.99 \\
\hline & & female & 193 & 2.24 & 0.85 \\
\hline & & Total & 405 & 2.98 & 1.16 \\
\hline & \multirow[t]{5}{*}{ Partnership\& resources } & Male & 212 & 3.80 & 0.85 \\
\hline & & female & 193 & 2.48 & 0.90 \\
\hline & & Total & 405 & 3.17 & 1.10 \\
\hline & & Male & 212 & 3.76 & 0.89 \\
\hline & & female & 193 & 2.39 & 0.88 \\
\hline
\end{tabular}




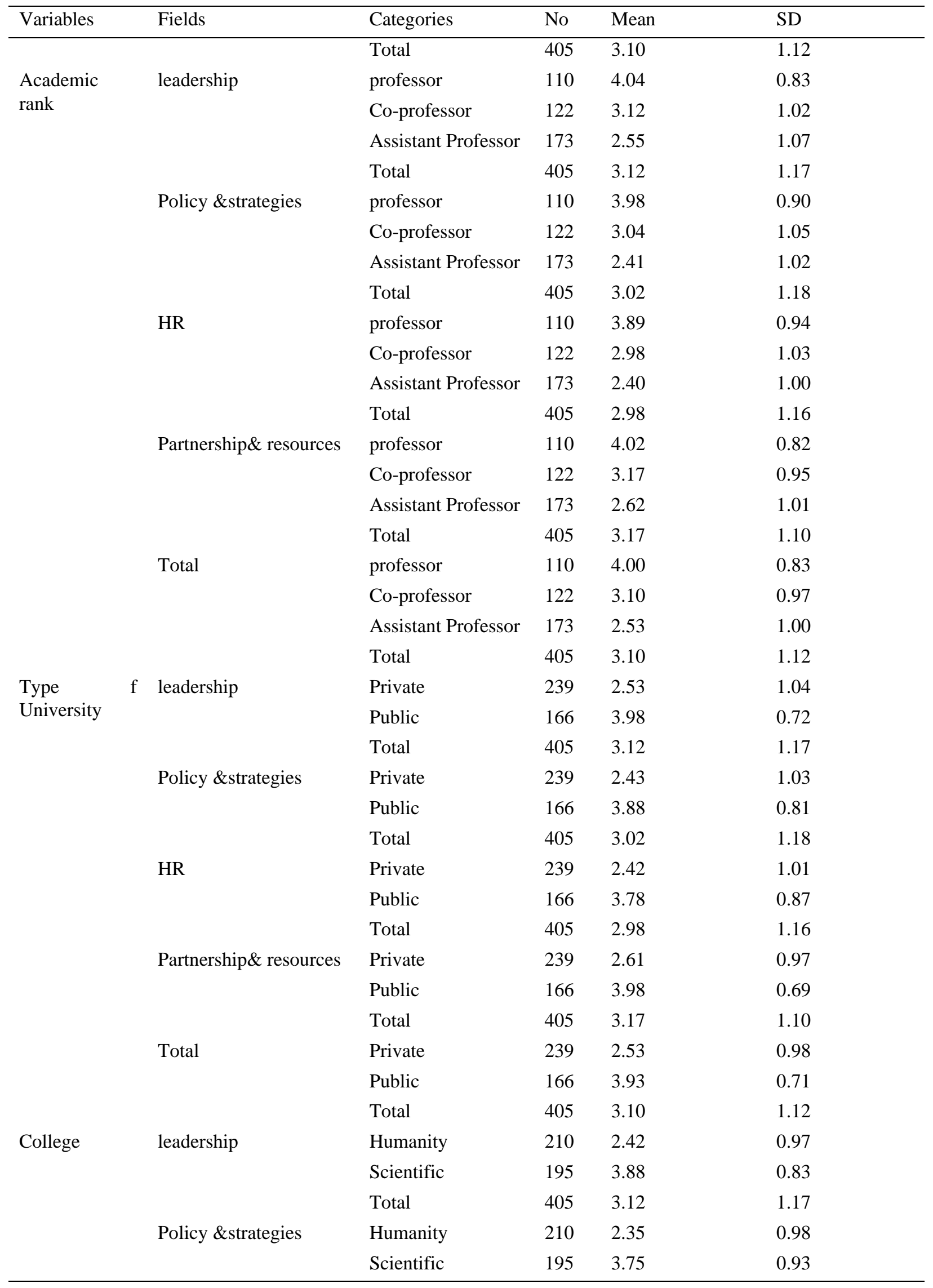




\begin{tabular}{|c|c|c|c|c|c|}
\hline Variables & Fields & Categories & No & Mean & SD \\
\hline & \multirow{4}{*}{$\mathrm{HR}$} & Total & 405 & 3.02 & 1.18 \\
\hline & & Humanity & 210 & 2.32 & 0.96 \\
\hline & & Scientific & 195 & 3.69 & 0.93 \\
\hline & & Total & 405 & 2.98 & 1.16 \\
\hline & \multirow{3}{*}{ Partnership\& resources } & Humanity & 210 & 2.52 & 0.93 \\
\hline & & Scientific & 195 & 3.87 & 0.79 \\
\hline & & Total & 405 & 3.17 & 1.10 \\
\hline & \multirow[t]{3}{*}{ Total } & Humanity & 210 & 2.43 & 0.93 \\
\hline & & Scientific & 195 & 3.83 & 0.80 \\
\hline & & Total & 405 & 3.10 & 1.12 \\
\hline
\end{tabular}

Table 7 shows an apparent difference in the means of the responses to the excellent management in Jordanian public and private universities among faculty members. To demonstrate the statistical differences between the mean, the (MANOVA) analysis was used using Wilk's Lambda test at the level of significance $(\alpha=0.05)$ for the responses of the participants on the fields and the overall score of the scale attributed to the study variables, as indicated in Table 8 .

Table 8 . The results of (MANOVA) for the responses on the excellence management among faculty members in public and private Jordanian universities due to the study variables.

\begin{tabular}{|c|c|c|c|c|c|c|}
\hline Source of variance & Fields & SS & $\mathrm{DF}$ & MS & F-value & Sig \\
\hline Gender & Leadership & 23.083 & 1 & 23.083 & 35.465 & .000 \\
\hline Wilk's $=0.983$ & Policies and strategies & 23.641 & 1 & 23.641 & 33.927 & .000 \\
\hline \multirow[t]{3}{*}{$\mathrm{Sig}=0.000$} & Human Resources & 31.474 & 1 & 31.474 & 45.730 & .000 \\
\hline & Partnerships and resources & 21.275 & 1 & 21.275 & 36.280 & .000 \\
\hline & The tool as a whole & 23.517 & 1 & 23.517 & 40.028 & .000 \\
\hline \multirow[t]{2}{*}{ Academic rank } & Leadership & 14.667 & 2 & 7.333 & 11.267 & .000 \\
\hline & Policies and strategies & 22.057 & 2 & 11.028 & 15.827 & .000 \\
\hline Wilk's $=0.985$ & Human Resources & 18.517 & 2 & 9.258 & 13.452 & .000 \\
\hline \multirow[t]{2}{*}{$\mathrm{Sig}=0.001$} & Partnerships and resources & 12.171 & 2 & 6.086 & 10.378 & .000 \\
\hline & The tool as a whole & 15.166 & 2 & 7.583 & 12.907 & .000 \\
\hline University type & Leadership & 5.113 & 1 & 5.113 & 7.856 & .005 \\
\hline \multirow{4}{*}{$\begin{array}{l}\text { Wilk's }=0.908 \\
\text { sig }=0.000\end{array}$} & Policies and strategies & 6.367 & 1 & 6.367 & 9.137 & .003 \\
\hline & Human Resources & 2.651 & 1 & 2.651 & 3.852 & .040 \\
\hline & Partnerships and resources & 6.260 & 1 & 6.260 & 10.676 & .001 \\
\hline & The tool as a whole & 5.271 & 1 & 5.271 & 8.972 & .003 \\
\hline Collage & Leadership & 16.688 & 1 & 16.688 & 25.639 & .000 \\
\hline \multirow{4}{*}{$\begin{array}{l}\text { Wilk's }=0.870 \\
\text { sig }=0.000\end{array}$} & Policies and strategies & 9.667 & 1 & 9.667 & 13.873 & .000 \\
\hline & Human Resources & 11.020 & 1 & 11.020 & 16.011 & .000 \\
\hline & Partnerships and resources & 11.552 & 1 & 11.552 & 19.700 & .000 \\
\hline & The tool as a whole & 12.562 & 1 & 12.562 & 21.381 & .000 \\
\hline \multirow[t]{5}{*}{ Error } & Leadership & 259.697 & 399 & .651 & & \\
\hline & Policies and strategies & 278.029 & 399 & 697 & & \\
\hline & Human Resources & 274.620 & 399 & .688 & & \\
\hline & Partnerships and resources & 233.973 & 399 & .586 & & \\
\hline & The tool as a whole & 234.415 & 399 & .588 & & \\
\hline
\end{tabular}




\begin{tabular}{|c|c|c|c|c|c|c|}
\hline Source of variance & Fields & SS & DF & MS & F-value & Sig \\
\hline \multirow[t]{5}{*}{ Adjusted total } & Leadership & 548.671 & 404 & & & \\
\hline & Policies and strategies & 565.932 & 404 & & & \\
\hline & Human Resources & 546.431 & 404 & & & \\
\hline & Partnerships and resources & 488.031 & 404 & & & \\
\hline & Total & 505.207 & 404 & & & \\
\hline
\end{tabular}

*Statistically significant at $(0.05=\alpha)$ level

Table 8 illustrates that:

1) There are statistically significant differences at the level of statistical significance $(\alpha=0.05)$ between the estimates of the respondents in all fields (leadership, policies, and strategies, human resources, partnerships, and resources) attributable to the difference in the gender variable, as the statistical value of the (f) test on the fields was (35.465). (33.927) (45.730) (36.280) with the level of significance $(0.000)(0.000)(0.000)(0.000)$ respectively and these values are considered statistically significant at $(0.05=\alpha)$, where the differences were in favor of males with a higher mean compared to females in all fields.

The researcher attributed this to the sample difference regarding the degree of the practicing excellence management in Jordanian public and private universities from the faculty members' point of view, and this result was consistent with the study of Enezi (2019) and differed with the study of (Hammoud, 2013; Saada, 2016; Maher, 2020; Perrini, 2015; Ahmed,2015). It also shows that there are statistically significant differences at the level of $(0.05)$ on the total score of the scale attributed to the effect of the gender variable, where the value of $(F)$ on the overall scale is (40.028) with a significance level $(0.000)$ and this value is statistically significant, as the differences were in favor of males with a higher mean compared to females on the scale.

2) There are statistically significant differences at the level of statistical significance $(\alpha=0.05)$ between the estimates of the respondents in all fields (leadership, policies, and strategies, human resources, partnerships, and resources) due to the difference in the academic rank variable, as the statistical value of the (f) test on the fields ( 11.267) (15.827) (13.452) (10.378) with a significance level $(0.000)(0.000)(0.000)(0.000)$, respectively, and these values are considered statistically significant at $(0.05=\alpha)$, where the differences were between the rank (Professor) and (Associate Professor) and in favor of the rank (professor), and between the academic rank ( professor) and( assistant professor) and it was in favor of the rank (professor) on all the fields.

The researcher attributed this to the sample difference regarding the tool fields, and this difference may be attributed to the diversity and multiplicity of the respondents' experiences and skills. This result agreed with the results of the study of Saada (2016), while it differed with the results of the study of (Hammoud, 2013; Maher, 2020; Moeini, 2015). It also shows that there are statistically significant differences at the level of significance (0.05) on the total score of the scale due to the effect of the variable of the academic rank, where the value of $(\mathrm{F})$ on the scale as a whole reached (12.907) with a level of significance (0.000). This value is statistically significant, as the differences were between the rank (professor) on the one hand and the rank (associate professor) on the other hand and the differences were in favor of the rank (professor), and differences between the rank (professor) on the one hand and the rank (assistant professor) and the differences were in favor of the rank (professor) ) on the scale.

There are statistically significant differences at the level of statistical significance $(\alpha=0.05)$ between the estimates of participants in all fields (leadership, policies, and strategies, human resources, partnerships, and resources) attributable to the difference in the university type, as the statistical value of the (f) test on the fields was (7.856) (9.137) (3.852) (10.676) with a significance level (0.005) (0.003) (0.040) (0.001) respectively, and these values are considered statistically significant at $(\alpha=0.05)$, where the differences were in favor of public universities with a higher mean compared to private universities on all areas. The researcher attributed this to the fact that public universities are more committed to standards and principles of excellence and overall quality to ensure the attainment of competitive advantage with Arab universities and high-quality, as it indicates the difference in regulations and instructions in public universities compared to private universities, and the results of this study are consistent with Saada (2016). Table (8) also shows that there are statistically significant differences at the level of significance $\left(\begin{array}{ll}0.05\end{array}\right)$ on the overall score of the scale attribute to the effect of the university type variable, as the value of $(F)$ on the overall scale is (8.972) with a level of significance (0.003). This value is considered statistically significant, the differences were in favor of public universities with higher mean compared to private universities on the scale. 
3) There are statistically significant differences at the level of statistical significance $(\alpha=0.05)$ between the estimates of respondents in all areas (leadership, policies, and strategies, human resources, partnerships, and resources) attributable to the difference in the college, as the statistical value of the (f) test on the domains reached (25.639) (13.873) ) (16.011) (19.70) with the level of significance (0.000) (0.000) (0.000) (0.000) respectively, and these values are considered statistically significant at $(\alpha=0.05)$, where the differences are in favor of scientific colleges with a higher mean compared to the human faculties on all fields. The researcher attributes this to the keenness of the scientific colleges to pay attention to qualitative, practical research with high productivity and with a continuous and advanced scientific return, which drives the educational institution towards excellence, development, and progress. The results of this study are inconsistent with Maher's (2020). The results also show statistically significant differences at the level of $(0.05)$ on the overall score of the scale due to the effect of the college variable, where the value of $(F)$ on the overall scale is (21.381) with a significance level (0.000), and this value is a statistically significant difference, as the differences are in favor of scientific colleges with a higher mean compared to the human faculties on the scale.

\section{Conclusion}

All educational institutions seek distinction through achieving a methodological framework for development, which is the management of excellence. Some universities tend to consider its department of quality assurance as an alternative to the department of excellence management, but to fulfill the requirement of excellence, all higher education institutions should strive to establish a special department of excellence, reduce all obstacles that hinder its application by adopting development plans and advanced educational systems. In addition to changing the method of work and focusing on flexibility in dealing with changing requirements occurring in higher education. This study shed the light on its results on the degree of the academics leaders' practice of excellence management, which came at a moderate degree, indicating that this resulted in several obstacles regarding leadership, policies, and strategies, human resources, partnerships, and resources. Therefore, this study came out with some recommendations.

\section{Recommendations}

- Encourage university and academic leaders to pay more attention to the Department of Excellence, especially in the field of human resources, by ensuring that multiple financial resources are given that cover and meet the University's needs to strive to provide sufficient financial resources from different sources.

- Develop transparent and detailed plans, methods, and processes for handling human resources, property, and technological facilities. Establishing mechanisms and strategies that emphasize and ensure a balance between the internal and current needs of the university and the local community, and work to strengthen the partnership between the university and the local community.

- Improve the degree of excellence management practice in Jordanian public and private universities by transferring them from the intermediate level to the higher level, reducing the gap in the degree of practice between graduates of private universities and graduates of public universities, and focusing on the continuous updating of their university plans.

- Conducting many studies dealing with the management of excellence according to different social variables and segments

\section{References}

Ahmed, M, J. (2015). Development of institutional performance at South Valley University considering the standards of excellence of the European Foundation for the Day of Quality - The European Model for Excellence in Management, Educational Administration Journal, 7(3), 15-176.

Annions, 1, N. (2007). The archetype of excellence in universities and TQM ", Journal of Management History, Vol.13. No.4, 307-321. https://doi.org/10.1108/17511340710819561

Brrazi, M. (2015). Requirements for the application of Excellence in Management at Kuwait University "Analytical Study". Journal of Scientific Research in Education, 16(2), 496-505.

Brusoni, M., Damian, R., Sauri, J., Jackson, S., Kömürcügil, H. Malmedy, M. Matveeva, O. Motova, G., Pisarz, S., Patricia, P., Rostlund, A., Soboleva, E., Tavares, O., \&Zobel, L. (2014). The Concept of Excellence in Higher Education. European Association for Quality Assurance in Higher Education. DOI - 10.13140/RG.2.1.2146.7683

Darwish, Z. (2008). Creativity in institutional work, obstacles, and coping mechanisms. The research of the Ninth Annual Conference: Towards a System for Arab Administrative Excellence, Cairo. 
Dhala'in, A, F. (2018). Proposed criteria for administrative excellence at the University of Jeddah considering the European model of excellence. Journal of Educational Sciences, 1(3), Jeddah, 409-420.

Enezi, K, J. (2019). The degree of the practice of high school principals in the State of Kuwait in managing excellence considering the European model of excellence, unpublished master's thesis, Al-Bayt University, Mafraq.

Maher, M. (2020). Requirements for the Application of Excellence Management Standards (EFQM) at Najran University considering some global experiences, Journal of the Association of Arab Universities for Research in Higher Education, Najran, 40.

Mahalaqi, S, S. (2018). Degree of application of the leadership of King Khalid University to the standards of management of excellence in light of the European model of excellence EFQM from the viewpoint of the faculty members at the university, International Society for Educational Research - UAE University, Volume 42, Issue 3, 155-195.

Moeini, A. N., Abdi, M, M., \& Afrassia, R. (2015). A study of the relationship between the EFQM organizational excellence model and the performance of the Joghatay Office of Education. ISSN: 2090-4274 Journal of Applied Environmental and Biological Sciences www.textroad.com.

Moerini, A, N., Abadi, M, M., \& Afrassiabi, R. (2015). A study of the relationship between the EFQM organizational excellence Model and the performance of Joghatay Office of Education, Journal of Applied Environmental and Biological Sciences, 5(10s), 631-639, ISSN: 2090-4274.

Mubarak, A. (2015). Requirements for the Application of Excellence in Management at Kuwait University - An Analytical Study, Journal of Scientific Research in Education, Issue 16(5), 509-510.

Nassif, M, \& Hashem, N (2010). A proposed vision for achieving distinction in Egyptian schools considering zthe International Excellence Awards, Journal of Studies for Educational Sciences, Volume (3), 16-22.

Perini, R (2015). The implementation of "EFQM" Excellence, MPA, Copenhagen Business school.

Saada, A. (2016). Applying Leadership criterion of EFQM Excellence Model in higher Education Institutions. UCAS AS A Case study. Thesis master's in business administration Islamic University, Gaza.

Sahamuod, I. (2013). The degree of the practice of school principals in managing excellence. Unpublished MA thesis, Islamic University, Gaza, Palestine.

Saud, R. (2009). Educational Supervision, Modern Trends, 1st Edition, Oman: Dar Al-Fikr Publishing.

Shawky, Q. (2010). Excellence management: the modern philosophy of the success of organizations in the era of globalization and competition. A working paper presented to the Fourth International Forum, Hassiba Ben Bouali University, Algeria.

Sreenivas, t et al. (2014). Towards Excellence in School Education TQM as A strategy, Research Journal of Social Science\& Management, Vol. (3), No. (10), 151-159.

Suhaimi, M. (2016). "The Implementation of Total Quality Management in King Saud University". International Journal of Independent Research Studies, 1(2), 80-88.

Tanash, S. (2020). The reality of the criteria used in selecting faculty members at Kuwait University from the point of view of academic leaders and faculty members, Journal of the Islamic University for Educational and Psychological Studies, Gaza University, 28(2), 786-809.

Sherbini (2011). The European Model for the Management of Excellence in Higher Education Institutions, the Arab Center for Education and Development.

Zoubi, A. (2019). The degree of practice of high school principals in Beni Kenana District in managing excellence according to the EFQM model for administrative excellence, Journal of educational and psychological studies, 103(2), 79.

\section{Copyrights}

Copyright for this article is retained by the author(s), with first publication rights granted to the journal.

This is an open-access article distributed under the terms and conditions of the Creative Commons Attribution license (http://creativecommons.org/licenses/by/4.0/). 